\title{
PELAKSANAAN PELAYANAN PRIMA TERHADAP KEPERCAYAAN NASABAH PADA PT. BANK PERKREDITAN RAKYAT JORONG KAMPUNG TANGAH PARIAMAN
}

\author{
Elva Susanti, Romi Susanto \\ Akademi Keuangan dan Perbankan "pembangunan"padang \\ elvasusanti850@gmail.com
}

\begin{abstract}
This research was conducted at PT. Jorong People's Credit Bank, Tangah Pariaman Village. The type of data collection used is Field Research and Research to the Library. Based on the research results it was found that the application of excellent service has been carried out by PT. Jorong People's Credit Bank, Tangah Pariaman Village, but the acceptance and response from some customers was not very good. The goal is to determine the process of implementing excellent service on customer trust in PT. Jorong People's Credit Bank, Tangah Pariaman Village. The method used is a qualitative method. With the results of this study, it can be applied (1) In the implementation of excellent service at the bank starting from being neat and polite, it can provide special services to customers, so that customers feel satisfied with the service they will receive. (2) Terms of service must be in accordance with standards and service is not making it up and always be honest in attitude. (3) Maintaining good relations between employees and customers so that customer trust is maintained. (4) Adding facilities and infrastructure in banks that support services. (5) Keeping abreast of the times in order to be able to compete with other banks in modern times like today.
\end{abstract}

Keywords: Implementing excellent service to customers at PT. BPR JKT

\section{PENDAHULUAN}

Bank merupakan lembaga keuangan atau perusahaan yang bergerak dibidang keuangan. Menurut Undang-Undang Nomor 10 Tahun 1998 tentang perubahan atas Undang-Undang Nomor 7 Tahun 1992 tentang perbankan, menyatakan bahwa bank adalah badan usaha yang menghimpun dana dari masyarakat dalam bentuk simpanan dan menyalurkannya kepada masyarakat dalam bentuk kredit atau bentuk-bentuk lainnya dalam rangka meningkatkan taraf hidup rakyat banyak. Bank sebagai perantara lembaga keuangan, di samping harus tetap menjaga kepercayaan masyarakat dengan menjamin tingkat likuiditas yang harus beroperasi secara efektif dan efisien untuk mencapai tingkat rentabilitas atau keuntungan yang memadai (Yuvendri \& Susanto, 2019).

Menurut (Putra \& Fernos, 2018) Bank Perkreditan Rakyat yaitu bank yang melakukan kegiatan secara konvensional atau berdasarkan prinsip syariah yang kegiatannya tidak memberikan jasa dalam bentuk lalu lintas pembayaran. 
Artinya Bank Perkreditan Rakyat hanya melakukan kegiatan berupa simpanan dalam bentuk deposito berjangka, tabungan, dan dalam bentuk lainnya yang di persamakan untuk menyalurkan dana sebagai usaha Bank Perkreditan Rakyat.

Pada Era Milenial, lembaga bank sangatlah penting dalam pelayanan prima terhadap kepercayaan nasabah. Semakin kita sadari bahwa pelayanan dan kepercayaan nasabah suatu kesatuan yang sulit di pisahkan dan merupakan sebuah aspek dalam rangka pertahanan bisnis untuk memenangkan persangian. Dalam dunia bank, khususnya di era milenial ini perbankan sangatlah ketat persangiannya, maka demi itu tidak dapat kita pungkiri lagi. Bank harus dapat dipercaya dalam pelayanan kepada nasabah bank tersebut. Karena prilaku nasabah terhadap bank dapat berubah dengan karakter nasabah yang berbeda-beda.

Menurut (lovenia, 2012) kualitas pelayanan merupakan suatu bentuk penilaian konsumen terhadap tingkat pelayanan yang akan diterima dengan layanan yang diharapkan. Dengan meningkatkan mutu pelayanan oleh suatu perusahaan perbankan yang merupakan suatu cara yang nyata dalam memenangkan persaingan dan mempertahankan nasabah. Sehingga kepuasan pelanggan dalam bidang jasa merupakan sangat penting untuk menentukan dalam menumbuhkan perkembangan perusahaan agar tetap eksis dalam menghadapi persaingan.

Adapun permasalahan mengenai fasilitas yang ada pada sebuah gedung dari bank-bank tersebut. Bahkan adapun permasalahan yang akan timbul dari pihak bank itu sendiri dalam mengenai Sumber Daya Manusia (SDM) yang kurang dalam memberikan pelayanan terhadap nasabah itu sendiri.

Permasalahan pelayanan dan kualitas terhadap nasabah dapat menimbulkan rintangan yang akan masuk lebih tinggi di dalam persaingannya, sehingga saat ini masih banyak lembaga perbankan yang belum menerapkan pelayanan prima terhadap nasabahnya. Bank yang berkualitas sangat berpengaruh kepada nasabah yang akan di hadapi dalam dunia perbankan itu sendiri, sehingga pihak bank harus memberikan fasilitas dan pelayanan yang memuaskan kepada nasabah itu sendiri karena prilaku nasabah memiliki bermacam-macam kepentingan.

Dalam dunia perbankan betapa pentingnya untuk memperoleh kepercayaan nasabah itu sendiri dan mempertahankan kepercayaan nasabah tersebut untuk keberhasilan bisnis bank. Sehingga bank berlomba-lomba dalam menunjukan sikap yang lebih menghargai nasabah dan mengembangkan pelayanan yang unggul. Bank bisa dikatakan kuat apabila memiliki kepercayaan dari nasabah itu sendiri. Namun sekuat apapun bank yang di maksud jika nasabahnya kehilangan kepercayaan bank tersebut tidak akan bertahan. Dalam hal ini bank juga harus menyadari apa yang menjadi tugas utamanya, yaitu dengan memenuhi kebutuhan nasabah-nasabahnya dan berusaha memuaskan nasabah.

Bisnis dalam perbankan memberikan pelayanan yang terbaik untuk memenangkan persainagan dalam dunia bisnis. Bisnis perbankan memberikan jasa yang berdasarkan pada azas kepercayaannya di dukung oleh keunggulan produk, serta pelayanan yang akan diberikan. Pernyataan tersebut di dukung oleh UU-RI No. 10/1998 tentang perbankan didalam pasal 29 dikatakan bahwa "mengingat bank terutama bekerja dengan dana dari masyarakat yang disimpan 
pada bank atas dasar kepercayaan, setiap bank perlu untuk terus menjaga kesehatannya dan memelihara kepercayaannya terhadap masyarakat untuk kedepannya".

Pelayanan prima pada hakikatnya yang berarti pelayanan yang di berikan secara maksimal atau pelayanan yang terbaik, dan merupakan salah satu faktor kunci utama dalam keberhasilan suatu bank. Dalam hal ini pelayanan prima harus dilakukan secara kontiniu dalam keadaan apapun. Sebab pada saat ini hakikatnya adalah menyediakan jasa yang harus tumbuh dan berkembang agar tetap bisa bertahan dalam melayani masyarakat dengan tujuan jangka pendek dan jangka panjang. Sehingga kepuasan pelanggan dapat tercapai dan dapat meningkatkan loyalitas pelanggan. Dan bank seharusnya melakukan pemantauan terhadap kepuasan yang telah diberikan kepada nasabah agar terjalinnya hubungan baik nasabah dengan bank tersebut sehingga dapat meningkatkan loyalitas nasabah.

Oleh sebab itu, diharapkan dengan melalui kegiatan pokok dalam bank. Bank dapat memberikan pelyanan melebihi yang diharapkan nasabah merupakan kebijakan yang perlu dikembangkan. Dengan demikian nasabah akan menjadi nasabah yang loyal untuk bisnis yang lebih besar lagi. Apabila memberikan pelayanan melebihi apa yang diminta nasabah, maka bank dimata nasabah memiliki reputasi yang baik. Untuk meningkatkan taraf hidup masyarakat. Tentu saja sangat diperlukan kepercayaan dari masyarakat tersebut dan kepercayaan ini akan diberikan kepada bank yang menurut mereka dapat memenuhi kebutuhannya yang akan memberikan pelayanan terbaik terhadap nasabah itu sendiri. Sehingga PT. Bank Perkreditan Rakyat Jorong Kampung Tangah Pariaman dapat melakukan pelayanan prima dalam meningkatkan kepercayaan masyarakat. Sebagai contohnya yaitu dengan melakukan pendekatan kepada nasabah secara langsung dengan cara pergi ketempat usaha yang berada di pasar pariaman lokasinya dekat dengan kantor PT. Bank Perkreditan Rakyat Jorong Kampung Tangah Pariaman tersebut.

Adanya beberapa kekurangan dalam Bank Perkreditan Rakyat Jorong kampung Tangah pariaman yaitu kurangnya karyawan pada bank tersebut sehingga pelayanan yang diberikan kepada nasabah belum efektif, tidak adanya nomor antrian di bank tersebut, membuat nasabah menjadi tidak beraturan dalam mengantri jika nasabah memiliki keperluan dalam bank ini. Produk-produk yang di tawarkan oleh bank perkreditan rakyat jorong kampung tangah pariaman kurang menarik sehingga tidak banyak nasabah yang ingin menabung pada bank tesebut, nasabah yang ingin meminjam uang untuk usahanya di bank perkreditan rakyat jorong kampung tangah pariaman agar dapat menjalankan prosedurnya dengan melakukan wawancara terlebih dahulu kepada nasabah yaang bersangkutan dan pihak bank melakukan survei dengan mendatangi kerumah nasabah tersebut, agar tidak akan terjadinya kredit macet atau penunggakan yang dilakukan nasabah.

Dari permasalahan diatas PT. Bank Perkreditan Rakyat Jorong Kampung Tangah pariaman harus menerapkan pelayanan prima agar dapat meningkatkan kinerja dalam bank, karena pelayanan sangat berpengaruh pada bank dan setor keuanagan dalam melakukan pelayanan yang efektif dan efesien. Hal yang harus diterapkan dalam pelayanan prima agar dapat memberikan nilai tambah pada bank 
perkreditan rakyat jorong kampung tangah pariaman dengan cara melakukan keterbukaan dengan nasabah, memperhatikan kebutuhan nasabah, melakukan keakraban atau pendekatan kepada pelanggan pada bank tersebut.

Berdasarkan dari paparan latar belakang tersebut, maka penulis berkeinginan untuk menerapkan betapa pentingnya pelaksanaan pelayanan prima terhadap kepercayaan nasabah agar nasabah akan merasa puas atas pelayanan yang diberikan, karena pelayanan merupakan salah satu aspek penting dalam usaha pokok pada bank untuk meningkatkan kepercayaan nasabah dan meningkatkan operasional pada bank perkreditan rakyat jorong kampung tangah pariaman tersebut. Maka penulis tertarik untuk mengambil judul mengenai "Pelaksanaan Pelayanan Prima Terhadap Kepercayaan Nasabah Pada PT.Bank Perkreditan Rakyat Jorong Kampung Tangah Pariaman".

\section{METODE PENELITIAN}

1. Metode Pengumpulan Data

Untuk keperluan penelitian ini, pengumpulan data dilakukan dengan dua cara yaitu:

a. Studi Perpustakaan

Penelitian perpustakaan ini bersifat teoritas yaitu penelitian yang dilakukan dengan cara mempelajari buku-buku, makalahmakalah, artikel-artikel, bacaan laporan-laporan dan publikasi yang berhubungan dengan objek penelitian. Agar mendapatkan pembahasan secara jelas yang menurut para ahlinya dan dapat ditarik kesimpulan sesuai keinginan penulis.

b. Studi Lapangan

Yaitu penelitian yang mendapatkan data sekunder dan melakukan pengamatan atau peninjauan langsung ke lingkungan perusahaan dengan wawancara pihak-pihak yang berperan langsung dalam proses pelaksanan pelayanan prima terhadap kepercayaan nasabahnya pada PT. Bank Perkreditan Rakyat Jorong Kampung Tangah Pariaman atau yang terkait dengan intansi bank tersebut.

2. Metode Analisa Data

Dalam menganalisa data ini, penulis menggunakan jenis data kualitatif, menurut sugiono (2016) dengan sebagai metode penelitian, dimana metode kualitatif menekankan kepada aspek pemahaman yang secara mendalam terhadap suatu masalah yang akan diteliti penulis menggambarkan dan menjelaskan data yang diteliti selama penelitian berlangsung pada PT. Bank Perkreditan Rakyat Jorong Kampung Tangah Pariaman. Tujuan dari metode penelitian ini bukan hanya saja untuk generalisasi akan tetapi dengan memahami secara mendalam terhadap suatu masalah yang diangkat oleh penulis tersebut.

\section{HASIL DAN PEMBAHASAN}

PT. Bank Perkreditan Rakyat Jorong Kampung Tangah Pariaman adalah kantor pusat yang dekat dengan pasar pariaman dan merupakan bank yang terpercaya, memiliki jaringan luas sehingga bisa dikatakan PT. Bank Perkreditan 
Rakyat Jorong Kampung Tangah Pariaman adalah bank yang sehat dan bisa di percaya. Produk-produk dari bank ini juga dapat bersaing dengan baik dari segi teknologi maupun kedekatan ke masyarakat melalui pelayanan prima.

PT. Bank perkreditan Rakyat Jorong Kampung Tangah Pariaman ingin memberi kehangatan kepada nasabahnya dengan memberikan pelayanan prima yang ramah, adil, cepat, tepat, akrab, dan etika yang baik sehingga memenuhi kebutuhan serta kepuasan yang di terima oleh nasabah. Untuk memenuhi kebutuhan nasabah pada PT. Bank Perkreditan Rakyat Jorong Kampung Tangah Pariaman dengan membuat unit pelayanan informasi yang juga menjadi sarana komunikasi pemasaran bagi bank yaitu costumer service atau pelayanan nasabah untuk mendukung kecepatan, ketepatan, dan keakuratan dalam bekerja pada PT. Bank Perkreditan Rakyat Jorong Kampung Tangah Pariaman.

Pelayanan prima sangat berpengaruh didalam PT. Bank Perkreditan Rakyat Jorong Kampung Tangah Pariaman untuk meningkatkan kualitas dalam pelayanan agar bank mampu untuk bertahan dan tetap mendapatkan kepercayaan penuh dari nasabah, maka terciptanya kepuasan dari nasabah itu sendiri terhadap bank perkreditan rakyat jorong kampung tangah pariaman.

Adanya dampak positif dari pelayanan prima terhadap kepercayaan nasabah pada PT. Bank Perkreditan Rakyat Jorong Kampung Tangah Pariaman yaitu:

Pertama yaitu dalam ciri-ciri pelayanan prima yang baik dengan meningkatnya kepercayaan nasabah adanya kontak langsung dengan nasabah dan keterbukaan pihak bank kepada para nasabahnya dalam memberikan informasi yang jelas, dapat memicu adanya rasa loyalitas terhadap bank tersebut dengan cara melayani nasabah secara cepat, tepat yang berarti pada saat proses pelayanan yang di lakukan di PT. Bank Perkreditan Rakyat Jorong Kampung Tangah Pariaman tidak terlalu lama dan menyambut nasabah dengan ramah dan sopan.

Yang kedua yaitu, untuk meningkatnya jumlah nasabah pada PT. Bank Perkreditan Rakyat Jorong Kampung Tangah Pariaman ada faktor pendukung dalam pelayanan prima karena adanya kesadaran karyawan bank terhadap tugasnya dalam melayani nasabah dengan tujuan untuk meningkatkan kualitas pelayanan prima terhadap kepercayaan nasabah agar nasabah akan tetap bertahan pada bank perkreditan rakyat jorong kampung tangah pariaman tersebut. Secara tidak langsung bank dapat melakukan strategi promosi terhadap orang terdekatnya yang biasa di sebut sebagai promosi dari mulut ke mulut (word of mouth). Dengan demikian, itu menunjang produktifitas bank atas pelayanan prima yang diberikan oleh bank. Tanpa adanya promosi yang di lakukan oleh bank maka nasabah tidak akan mengenali PT. Bank Perkreditan Rakyat Jorong Kampung Tangah Pariaman.

Yang ketiga yaitu, adanya strategi pelayanan prima dalam meningkatkan kepuasan nasabah pada PT. Bank Perkreditan Rakyat Jorong Kampung Tangah Pariaman, dalam menjaga hubungan yang baik karyawan dengan nasabah agar terciptanya kesan lebih baik terhadap nasabah yang akan melayani, hubungan ini terkait karena keterbukaan pihak bank dalam melayani nasabah yang membuat nasabah merasa nyaman dan aman saat melakukan kegiatan transaksi atau membeli produk-produk yang di tawarkan oleh bank perkreditan rakyat jorong kampung tangah pariaman. Dan strategi jemput bola, strategi ini sangat efektif 
dilakukan di PT. Bank Perkreditan Rakyat Jorong Kampung Tangah Pariaman, karena karyawan bank melakukan dengan cara mendatangi langsung nasabahnya dalam menyediakan jasa atau produk yang diberikan. agar karyawan akan lebih dekat dengan nasabahnya dan dapat memberi kemudahan terhadap kebutuhannya.

Yang keempat adalah membaiknya oprasional pada bank dan dapat memperpanjang umur terhadap bank, kepuasan sangat berpengaruh terhadap kepercayaan dari nasabah terhadap pelayanan yang di dapatkan karena nasabah akan royal dan setia kepada bank, nasabah akan mudah menerima produk-produk yang diberikan, agar nasabah royal terhadap bank maka tingkan standar karyawan dan staf bank akan meningkat dengan memberikan pelayanan yang sesuai dengan 5S (senyum, salam, sapa, sopan, santun).

Pelaksanaan pelayanan prima pada PT. Bank Perkreditan Rakyat Jorong Kampung Tangah Pariaman telah dilakukan dengan baik dan sesuai yang telah ditentukan. Namun, melalui pengamatan penulis pelayanan prima tidak berlaku pada beberapa nasabah karena nasabah tersebut tidak terlalu mementingkan pelayanan tersebut. Dapat memberi kepercayaan penuh terhadap kepuasan nasabah adalah tujuan dari pelayanan prima di PT. Bank Perkreditan Rakyat Jorong Kampung Tangah Pariaman agar dapat mengambil hati nasabah untuk menabung dan menggunakan jasa bank. Kepercayaan akan timbul apabila pelayanan yang di berikan mendapat respon dari nasabah.

\section{SIMPULAN}

Dari analisis yang telah dilakukan pada bab sebelumnya, dapat ditarik beberapa kesimpulan sebagai berikut:

1. Dalam pelaksanaan pelayanan prima pada PT. Bank Perkreditan Rakyat Jorong Kampung Tangah pariaman dimulai dari berpenampilan rapi dan sopan dapat memberikan layanan yang istimewa kepada nasabah, agar nasabah merasa puas atas layanan yang akan diterimanya.

2. Karyawan dan staf pada PT. Bank Perkreditan Rakyat Jorong Kampung Tangah Pariaman harus menjaga hubungan baik karyawan dengan nasabahnya. Untuk meningkatkan kualitas pelayanan prima terhadap kepercayaan nasabah dengan cara memberikan 5S yaitu senyum, salam, sapa, sopan, santun.

3. Langkah-langkah yang harus diterapkan dalam pelayanan prima pada PT. Bank Perkreditan Rakyat Jorong Kampung Tangah Pariaman yaitu sebagai berikut:

a. Menjaga hubungan baik karyawan dengan nasabah bank

b. Mudah dan cepat dalam memberikan pelayanan

c. Melakukan keterbukaan kepada nasabah

d. Memperhatikan kebutuhan dari nasabah

e. Lebih dekat secara pribadi

4. Kepercayaan sangat penting dalam pelayanan prima terhadap kepuasan nasabah agar dapat bertahan dan setia pada PT. Bank Perkreditan Rakyat Jorong Kampung Tangah Pariaman. 


\section{UCAPAN TERIMA KASIH}

Penulis mengucapkan terima kasih kepada:

1. Kedua orang tua yang senantiasa merawat dan mndidik serta mncurahkan kasih sayang pada penulis.

2. Direkur AKBP beserta prodi AKBP serta bapak ibuk dosen yang tela mendidik dan mmberikan ilmu pngetahuan kepada penulis.

3. Pemimpin PT. BPD Sumatera Barat Cabang Pembantu Aur Kuning yang telah mengizinkan penulis memperoleh informasi

4. Kepada semua piak yang telah membantu dalam membuat tugas akhir.

\section{DAFTAR PUSTAKA}

Ascarintya, P. (n.d.). Analisis Pengaruh Pelayanan Terhadap Kepuasan Nasabah PT. BPR Satria Pertiwi Semarang.

Fitri, U. S. (2011). Penerapan Pelayanan Prima Kepada Nasabah Di Perusahaan Daerah Bank Perkreditan Rakyat Sarimadu Bangkinang.

Fernandes, Y. D., \& Marlius, D. (2018). Peranan Customer Service Dalam Meningkatkan Pelayanan Kepada Nasabah Pada PT. Bank Pembangunan Daerah Sumatera Barat Cabang Utama Padang. https://doi.org/10.31227/osf.io/wrh3p

Fernos, J., \& Putra, Y. E. (2019). Analisa Pengaruh Kualitas Pelayanan Terhadap Kepuasan Nasabah Pada PT. Bank Mega Syari'ah Padang. https://doi.org/10.31219/osf.io/y2baf

Halimah, P. (2018). Pengaruh pelayanan prima terhadap kepuasan nasabah bprs dharma kuwera. 74.

Kasmir. (2014). Bank Dan Lembaga Keuangan Lainnya. Edisi Revisi 2014 PT Raja Grafindo Persada Jakarta.

Kotler, P. (2002). Manajemen Pemasaran (Jilid 1. E). Jakarta Prehalindo.

lovenia, chistiana okky. (2012). Analisis pengaruh kualitas pelayanan terhadap kepuasan nasabah. 63.

Marlius, D. (2018). Loyalitas Nasabah Bank Nagari Syariah Cabang Bukittinggi Dilihat Dari Kualitas Pelayanan. Jurnal Pundi. Volume 1. No. 3. Hal.1222. https://doi.org/10.31575/jp.v1i3.60

Marlius, D. (2018). Pengaruh Dimensi Kualitas Pelayanan Website Akademik Terhadap Kepuasan Mahasiswa Pada STIE “KBP”. Jurnal Ipteks Terapan. $\begin{array}{lllll}\text { Volume } & 12 . & \text { No. } & \text { Hal. } & 116-128 .\end{array}$ http://doi.org/10.22216/jit.2018.v12i2.633

Putra, Y. E., \& Aziz, N. (2019). Pengaruh Kualitas Pelayanan Dan Kepuasan Pelanggan Terhadap Loyalitas Nasabah PT. Bank Rakyat Indonesia Cabang Padang. https://doi.org/10.31219/osf.io/hcsw2

Putra, A. M., \& Fernos, J. (2019). Pelaksanaan Pelayanan Prima Terhadap Kepercayaan Nasabah Di PT. Bank Perkreditan Rakyat Jorong Kampung Tangah Pariaman. https://doi.org/10.31227/osf.io/c3fy4

Sholihat, I., \& Susanto, R. (2019). Peranan Account Officer Pada PT. Bank Perkreditan Rakyat Ganto Nagari 1954 Lubuk Alung. 
https://doi.org/10.31219/osf.io/kcsz9

Sinungan, M. (1997). Manajemen Dana Bank. PT. Bumi Aksara.Jakarta.

Sugiarthi, N. M., Nuridja, I. M., \& Indrayani, L. (2014). Pengaruh Kualitas Pelayanan Terhadap Kepuasan Nasabah Pada PT. BPR Ulatidana Rahayu Di Kecematan Sukawati. 1.

Wahyuni, S., \& Widayati, R. (n.d.). Upaya Meningkatkan Minat Untuk Menabung Pada PT. BPR Batang Kapas. 1-8.

Yuvendri, R., \& Susanto, R. (2019). meningkatkan mutu pelayanan dalam usaha menghimpun dana masyarakat (tabungan) pada PT. Bank Perkreditan Rakyat Prima Mulia Anugrah Cabang Padang. 1-11. 